\title{
1. Marlowe's violent reformation: religion, government and rebellion on the Elizabethan stage
}

\section{Kristin M.S. Bezio}

On 23 August 1572, the French Duke of Guise ordered the systematic slaughter of French Huguenots in Paris. Begun with a failed (later successful) assassination attempt on Admiral Coligny on 22 August, the St. Bartholomew's Day Massacre rapidly devolved into mob violence and spread throughout the region, leaving thousands dead. One of its witnesses was an Englishman living in Paris, Sir Francis Walsingham, then Elizabeth's Ambassador to France. During the events of August 1572, Walsingham opened his house to shelter potential victims of the Massacre. ${ }^{1}$ The following year, Walsingham, having returned to England, was to be promoted to the position of Secretary of State and assume control of the Elizabethan spy network.

One of the spies in his service was a Canterbury man by the name of Christopher Marlowe. The Cambridge graduate and future playwright joined the government network some time between 1584, when he took his Bachelor's degree, and 1587, when the Privy Council intervened on his behalf with the university, which was refusing to grant his Master's on the grounds that he was a secret Catholic.

Beginning in 1585, Marlowe was frequently absent from classes, and it was suspected that he had traveled abroad to Rheims in France, where the Jesuit William Allen had established an English Catholic seminary. ${ }^{2}$ During this time, biographers note, Marlowe began spending more money on food and his friends, a distinct change from his frugality in previous years. ${ }^{3}$ This suggests, argue A.L. Rowse, David Riggs and Park Honan, that the peripatetic scholar had acquired a secret source of income commensurate with the pay expected of an Elizabethan secret agent. ${ }^{4}$

When coupled with the apparent coincidence of many of Marlowe's acquaintances being themselves in the employ of the government-among them Richard Baines, Robert Poley, Gifford Gilbert, Nicholas Skeres and Ingram Frizer (the last of whom was personally responsible for Marlowe's 
untimely death) — or in positions of considerable political power-Francis and Thomas Walsingham, Sir Walter Raleigh and Henry Percy, Earl of Northumberland - it seems likely that Marlowe, too, was a government agent.

As such, Marlowe would have been in a position not only to have heard Walsingham's account of the St. Bartholomew's Day Massacre (either personally or second-hand), but to have been a first-hand witness to the violence and cruelty occasioned by the question of religion in Reformation England. Although only an eight-year-old boy at the time of the Massacre, Marlowe was clearly impacted by the event, both imaginatively and professionally. As David Riggs notes, the word "massacre" itself-French in origin, meaning "slaughterhouse"-was imported into the English language by the French Huguenots fleeing persecution, some of whom ended up in Marlowe's native Canterbury. ${ }^{5}$ The association of the Massacre with a slaughterhouse came from the fact that when French soldiers refused to participate in the killing, the task was given to the butchers. ${ }^{6}$ Furthermore, Riggs remarks, "The eight-year-old Christopher Marlowe, living on the edge of the town shambles, could readily grasp the sense of this metaphor. Armed men butchered their prey in a killing field; the carnage reduced human beings to the status of livestock; blood and body parts littered the streets." " These images recurred frequently in Marlowe's dramatic works, including Edward II, Jew of Malta, Doctor Faustus and, of course, Massacre at Paris.

\section{MARLOWE AS CULTURAL LEADER}

So how, then, ought we to consider Marlowe as a figure for cultural leadership? Certainly, his dramatic innovations paved the way for the future of Elizabethan and Jacobean drama, and, by extension of his influence on one William Shakespeare, all of English literature. But of greater interest to me is the way in which Marlowe sought to lead - to use the term somewhat loosely - through the influence of his work.

Marlowe's leadership, in the sense in which I use it here, took place on the public stages and through the printed pages of early modern London, both during and after his life. As an agent of Elizabeth's all-buttotalitarian government, Marlowe was most likely a party to political and courtly details which would have been beyond the rank of the majority of his peers, whether at Cambridge or in Southwark. As such, Marlowe's plays are uniquely political and particularly critical, with an edge of cynicism and a lack of regard for his own reputation that only an agent secure in his position could attempt. 
Repeatedly - as we have seen - throughout his career Marlowe was accused of and even formally charged with offenses which would have meant fines, imprisonment and even death for others. Doctor Faustus transgressed the boundaries of both propriety and religious tolerance by actively staging a demonic summoning complete with ritual words; Jew of Malta contains contentious depictions of Christians and non-Christians alike, including Barabas's diatribe against religion; Edward II stages the graphic and sodomitical death of an anointed king; and Massacre at Paris depicts a political event which happened during the lifetimes of most living adults and includes reference to the living English Queen. In so doing, Marlowe changed the face of the English stage, not simply in terms of defining the genre, but in actively promoting his own political, social and (anti-)religious agenda.

The theatrical stages of early modern London played to a public audience of approximately one thousand patrons a day, affording dramatists like Marlowe a distinctive opportunity to engage the public en masse. ${ }^{8}$ And this engagement - although ostensibly regulated by the Office of the Revels under the control of the Privy Council - came to define both the value and the danger of the theaters; they could serve both to circulate propaganda and to subvert the dominant paradigm, often (and, especially in Marlowe's case) simultaneously:

In short, while offering a site of governmental ideological dissemination, playhouses nevertheless implicitly threatened the very regime that sanctioned their authority, in large part because of the scope and impressionability of the audience contained within their walls, but also because of the potential for the plays themselves to influence that audience. ${ }^{9}$

As a playwright, then, Marlowe had the ability to speak-through the actors performing his plays - to an audience of thousands; as a government agent of some value, he was given the license (literally, from the Office of the Revels) to be even more subversive than his contemporaries, an opportunity of which he took full advantage, writing plays which staged material that bordered on the seditious and heretical. His followers-his audience - were more than receptive, making Marlowe's drama among the most popular in early modern England.

\section{AGENT AND "ATHEIST"}

By January of 1593, when Massacre at Paris appeared on the stage of Philip Henslowe's Rose Theatre to great popular acclaim, Marlowe was an 
experienced spy and playwright, a rising star on the Elizabethan dramatic stage. It was Marlowe who was responsible for the introduction of blank verse to the public theaters and who, Roy Kendall explains, "began the move that eventually led to the play form being taken up by some of the keenest minds of their respective generations" as not simply a pastime, but a career. ${ }^{10}$ As one of early modern drama's first published and named playwrights, Marlowe helped to shape not only the form, but the frequently subversive content of the early modern public theaters.

As a government agent, Marlowe's intellect was both an asset and, if his behavior stateside is any indication, a liability. While in the Netherlands, Marlowe and Baines were both found guilty of currency forgery and functionally deported. Years later, Baines accused Marlowe of atheism, a charge that led to a warrant for his arrest in 1593, although both "the minutes of the Council, as well as the warrant for Marlowe's apprehension, are silent about the nature of the charges." 11 Arrested on 20 May, Marlowe was immediately released, suggesting that "the Council did not take the matter too seriously, very probably," Samuel Tannenbaum argues, "because it knew that Marlowe was one of the Queen's secret agents."12 Nine days later, the Privy Council received the Baines Note, a document which details Marlowe's (supposed) heretical opinions, including the infamous statements "that Moyses was but a Jugler \& that one Heriots being Sir W Raleighs man can do more then he" and "That Christ was a bastard and his mother dishonest."13

The Baines Note tells us more than just Marlowe's (probably drinkinduced) views on religion; it reveals his intimacy with Sir Walter Raleigh, prominent courtier, sometime favorite of the Queen, part-time spymaster and member of the "atheistic" School of Night. The School was a group of men surrounding Raleigh and which included the poet George Chapman, mathematician Thomas Heriot, and the "Wizard Earl" of Northumberland, Henry Percy. The charge of atheism leveled at these men came specifically from a Jesuit, Robert Parsons, a man who undoubtedly had reason to harbor distaste for men like Raleigh and Marlowe, whose job it was to root out and expose Catholic agents like Parsons. As such, the Baines Note shows a picture of a man who not only sought to impress his companions with his daring opinions, but who was intimate with some of the leading - and politically powerful—"atheists" of his time.

It is worth noting that "atheism" in early modern parlance is not the same as modern atheism (a lack of belief in a God or gods). To early moderns, "atheism" included "the denial of the validity of the Scriptures, deism, agnosticism, Arianism, and sometimes, it would seem, any extreme or radical religious belief," explains George T. Buckley. ${ }^{14}$ As such, Marlowe's claim that "Moyses was but a Jugler" and, especially, that "Christ was a bastard" would easily have fallen within such a definition. 
But what did Marlowe really believe? Although it is difficult to ascertain for certain just how seriously Marlowe believed the assertions in the Baines Note (assuming Marlowe did indeed say any of the things recorded therein), there is evidence to suggest that Marlowe's beliefs were unconventional, even "radical." In addition to the Note, the Privy Council's search of the chambers Marlowe shared with another playwright, Thomas Kyd, revealed a heretical treatise which $\mathrm{Kyd}$ - undoubtedly wanting to save his own skin - claimed belonged to Marlowe. The contents of this tract appear to have been Socinian, a branch of Protestantism which formed in Poland in the sixteenth century and ultimately gave rise to Unitarianism.

The tenets of Socinianism "rejected not only the central doctrines of the Trinity and the deity of Christ, but a raft of subordinate doctrines, including original sin, total depravity, predestination, vicarious atonement, and eternal punishment," explains Leonard Smith, any of which would have earned it the label of "atheism" in Elizabethan England. ${ }^{15}$ Although we cannot be certain of Marlowe's personal beliefs, there are hints throughout his plays which suggest his familiarity with Socinian doctrine. Massacre at Paris contains several references to Poland, the birthplace of Socinianism and Faustus Socinus, its founder, whose name seems too coincidental not to have had some connection to Marlowe's Doctor Faustus. Furthermore, Doctor Faustus mentions one "princely Sigismund" (DFb 3.1.146), which Edgar C. Knowlton suggests - contrary to popular readings-refers to a sixteenth-century Polish king (rather than the presumed fourteenthcentury German Emperor):

If we recall that Marlowe's was the century of Popes Julius II and Julius III, and that Sigismund I was King of Poland from 1506 to 1548, and that Sigismund II was King of Poland from 1548 to 1572, the possibility that a Polish Sigismund might be relevant is hard to overlook. ${ }^{16}$

Since Socinus completed his De Sacrae Scripturae Auctoritate around 1575 , the suggestion that "princely Sigismund" refers to a contemporary Polish king rather than the German emperor (whose reign did not overlap with a Julian papacy) seems reasonable. ${ }^{17}$ When examined as one of several allusions to Socinianism - which was also popular among the School of Night - it seems an intentional reference. Whether Marlowe believed in its doctrine we cannot know, but its radicalism and rejection of Christ's divinity would certainly have appealed to his contrarian nature.

When we consider Marlowe's work, then, it is important to remember his incredulity in matters of religion. In particular, when we examine characters of faith, we must consider them from Marlowe's perspective, not just the perspective of the accepted orthodoxy of his day. For Marlowe, 
Protestant zealotry would have been as worthy of derision as Catholic devotion: indeed, if Baines is to be believed, Marlowe was of the opinion "That if there be any god or any good Religion, then it is in the papistes."18 Given this, it becomes difficult to read Massacre at Paris-the most directly anti-religious of Marlowe's plays - as anything but a criticism of both Catholics and Protestants which seeks to expose the hypocrisy found in adherents of both.

\section{MASSACRE AT PARIS}

Henslowe's Diary gives the weekly income for a play referred to as the "tragedy of the gvyse," played by Lord Strange's Men on 30 January 1593 as $£ 3$ 14s, an income that, Kristen Poole notes, "was the highest of the season," exceeding by $£ 2$ the average weekly income for a play, concluding that this "initial and sustained popularity indicates that The Massacre at Paris profoundly resonated with Elizabethan interests and concerns." 19 Gruesome and bloody, Massacre at Paris has been widely maligned by critics for its macabre content, as well as the poor state of the only extant text, generally believed to be an actor's copy. ${ }^{20}$ Yet the seeming propagandism and anti-Catholic sentiment of the play ought to be questioned, as Julia Briggs astutely observes, since "in Marlowe's dramaturgy things are so seldom exactly what they seem." ${ }^{21}$ Like Briggs, I find Marlowe's "obviousness" to be highly suspect, and instead argue that what appears to be trite propaganda catered to the tastes of the lowest common denominator is in fact a scathing denouncement of Elizabethan religious policy. ${ }^{22}$

The play, with Marlovian irony, opens with the marriage of Henry of Navarre to Margaret, sister of King Charles IX of France. Charles blesses the wedding as a union of both family and religion, saying: "I wish this union and religious league, / Knit in these hands, thus join'd in nuptial rites, / May not dissolve till death dissolve our lives" (1.3-5). The wedding concludes with a mass, and the Queen Mother, Catherine de Medici, gives an aside in which she says she will "dissolve" the union "with blood and cruelty" (1.25). This early reference to the mass links the Catholic sacrament with the impending slaughter of the massacre, as, John Guillory argues, "for Marlowe the St. Bartholomew's Day Massacre and the Catholic mass can be understood as joined at the root, socially if not linguistically," as "mass" quite literally begins the word "massacre." 23 The mass also serves here as a kind of Black Mass, a ritual consumption of flesh and blood partaken prior to an act of treason or witchcraft. For Elizabethans, the one was barely separable from the other in popular 
culture, and the reference to Catholic ritual would immediately vilify the participants.

The ritual provides the frame for the rest of the play, the general plot of which would have been familiar to Marlowe's audience, since, according to Paul Voss, "the wars in France received more extensive coverage in the press than any other news event during the reign of Elizabeth I," including the defeat of the Spanish Armada in $1588 .{ }^{24}$ In 1593, the year in which Massacre at Paris first appeared on stage, the French religious wars were not yet over, and Elizabeth had recently sent the Earl of Essex-with whom Marlowe, as a government agent, was likely also acquainted-to assist Henry IV in liberating Rouen from Catholic forces. ${ }^{25}$ This also meant, of course, that Marlowe's audience likely understood far too well the consequences of religious wars across the Continent, as it was from their numbers that the soldiers were sent to assist the Protestant cause abroad. So while Massacre at Paris is certainly propagandistic in places, it also provides a reminder to the English audience that they, too, were being asked to risk their lives in foreign wars.

In order to mitigate this criticism, however, Marlowe provides an appropriate villain for his play: the Machiavellian Duke of Guise, who, Navarre explains once the Catholic royals have left the stage, "seeks to murder all the Protestants" (1.30). Yet Marlowe does not vilify the Guise alone, attributing violence to Catholicism more generally when Condy explains that "what he doth the Pope will ratify - / In murder, mischief, or in tyranny" (1.39-40). Navarre is quick to remind him - and the Elizabethan audience-that:

NAVARRE He that sits and rules above the clouds

Doth hear and see the prayers of the just,

And will revenge the blood of innocents

That Guise hath slain by treason of his heart

And brought by murder to their timeless ends. (1.41-45)

Navarre's prediction thus serves two purposes: first, to remind the audience that they are among God's chosen; and, second, to introduce the play's central villain-hero.

The Guise himself appears almost immediately following Navarre's naming of him, a demon summoned to the stage upon being invoked. He also immediately confirms the audience's expectations of his villainy by proclaiming his aspirations to "the diadem of France" (2.41) in full Machiavellian style:

GUISE For this, hath heaven engender'd me of earth;

For this, this earth sustains my body's weight, 
And with this weight I'll counterpoise a crown

Or with seditions weary all the world;

For this, from Spain the stately Catholics

Sends Indian gold to coin me French ecues;

For this, have I a largess from the Pope,

A pension and a dispensation too;

And by that privilege to work upon,

My policy hath fram'd religion.

Religion: O Diabole! (2.53-63)

Here, Marlowe's play smacks strongly of propaganda, situating Navarre (Elizabeth's ally) in direct opposition to the Guise and Spain (Elizabeth's avowed enemy). For the early portions of the play, Marlowe maintains the appearance of Protestant nationalism, although it is a nationalism he complicates in Massacre at Paris's final scenes.

In the following scene, the Guise and Catherine propose the Massacre to Charles as a means "to seek your country's good" (3.19). Charles protests, explaining that:

KING CHARLES my heart relents that noble men,

Only corrupted in religion,

Ladies of honour, knights, and gentlemen,

Should for their conscience taste such ruthless ends. (4.9-12)

These lines, divorced from a specific religious (or theatrical) context, could apply equally to either Elizabeth or Charles, and serve as an indication that it is violence in the name of religion, rather than a specific religion in and of itself, that is Marlowe's target in Massacre at Paris. In his argument for the Massacre, the Guise equates France with Catholicism, combining church and state in a manner much more reflective of the English theocratic monarchy than of France. Furthermore, it was an argument that would have resonated with the Elizabethan government, which, in the years leading up to the play's appearance, had executed Mary Queen of Scots (1587), convicted nobles involved in the Babington Conspiracy against Elizabeth (1586/7), and purged Catholic sympathizers in anticipation of the arrival of the Armada (1588) ${ }^{26}$ Like the Guise, Elizabeth's government chose their "country's good" rather "Than pity or relieve these upstart heretics" (4.20).

But Marlowe does not allow the audience much time to dwell on such ideological similarities, and immediately plunges into the carnage of the Massacre. Although Joan of Navarre is arguably the first victim - poisoned (ahistorically, it is worth noting) by a pair of gloves in Scene III - the Admiral's death in Scene V is the first "official" death in the Massacre. $\mathrm{He}$ 
is stabbed by Gonzago with the injunction to "kiss this cross" (5.28), and his body thrown into the street at the Guise's command. ${ }^{27}$ Anjoy orders the soldiers to "cut off his head and hands - / And send them for a present to the Pope" (5.42-43). ${ }^{28}$ The deed being done, the Guise commands that the signal be given to initiate the Massacre city-wide:

GUISE Mountsorrell, go shoot the ordinance off,

That they which have already set the street

May know their watchword; then toll the bell

And so let's forward to the massacre. (5.53-56)

The Massacre proper begins with a preacher-Loreine-perhaps a reflection of the Elizabethan government's active pursuit of Catholic priests. The next is Seroune, whose occupation is unknown, followed by the scholar Ramus. ${ }^{29}$ Following Ramus's death, the Guise calls out:

GUISE My Lord of Anjoy, there are a hundred Protestants

Which we have chas'd into the river Seine

That swim about and so preserve their lives:

How may we do? I fear me they will live.

DUMAINE Go place some men upon the bridge

With bows and darts to shoot at them they see,

And sink them in the river as they swim. (9.56-62)

Next, the Guise and his men kill two schoolmasters, tutors to Prince Condy, then "five or six Protestants with books" (12.0.1). Thus far, it is worth noting the demographics of Marlowe's Massacre victims - those in the Seine aside. As Paul Kocher remarks,

Marlowe is particularly profuse with the blood of scholars and preachers, all five of the persons he chooses for extinction being one or the other. Scholars, perhaps, Marlowe was personally interested in; preachers helped to emphasize the religious quarrels involved, and their deaths would evoke the strongest indignation of the English audience. ${ }^{30}$

This is to say nothing of the fact that Marlowe, as a government agent, would have been particularly cognizant of the role of both scholars - as those likely to defect to Rheims - and preachers-like the Jesuits he was paid to hunt - in the religious cold war between English Protestants and Catholics.

It is perhaps unsurprising, therefore, that Marlowe returns to the idea of the "country's good" following these scenes of murder; Cardinal Lorraine, at the coronation of Henry III (formerly Anjoy), urges Catherine to "insinuate with the King / And tell him that 'tis for his 
country's good, / And common profit of religion" (14.57-59). The Cardinal's language mimics the sentiments contained in the Elizabethan Bond of Association (1584) - requiring Elizabeth's subjects to defend her with their lives, targeted specifically at Recusants and, particularly, at Mary Queen of Scots, whose death it assured. ${ }^{31}$ The Bond, like the Cardinal's exhortation, prioritized the sovereign not only as the head of the nation, but - as Elizabeth herself reminded Parliament at its closing in 1585 - of "the Church, whose overruler God hath made me, whose negligence cannot be excused if any schism or errors heretical were suffered." 32 As in the earlier scene in which the Guise invokes the "country's good," however, Marlowe moves on swiftly, not dwelling too long on a statement at once treasonous and-given the close ties between the Elizabethan church and state- -heretical.

At this point, the play abruptly jumps forward historically, juxtaposing the Massacre of 1572 with the deaths of the Guise in 1588 and Henry III in 1589, two events much more contemporary to the play's composition. Mere pages later, at the opening of Scene XVI, Navarre's discourse echoes the language of providential justification with which he began the play, and he, interestingly, repeats the refrain of "country's good" (16.11) employed earlier by the Guise and Lorraine:

NAVARRE My Lords, sith in a quarrel just and right

We undertake to manage these our wars

Against the proud disturbers of the faith -

I mean the Guise, the Pope, and King of Spain,

Who set themselves to tread us under foot

And rent our true religion from this land

(But for you know our quarrel is no more

But to defend their strange inventions

Which they will put us to with sword and fire) -

We must with resolute minds resolve to fight

In honour of our God and country's good. (16.1-11)

The fact that Navarre, too, draws upon the language of the common weal further problematizes an already fraught expression in the play. If both sides can claim the "country's good," then the only thing that becomes clear is that neither has its "country's good" at heart; war in the name of religion, although justified in the name of country and common good, can, by extrapolation, only do the country (and her people) harm, a point Massacre at Paris goes on to illustrate with further bloodshed.

Protestant retribution for the earlier Massacre begins with the death of Henry III's General Joyeux offstage, the announcement of which spurs the play's first direct reference to England: 
NAVARRE But God, we know, will always put them down

That lift themselves against the perfect truth,

Which I'll maintain so long as life doth last,

And with the Queen of England join my force

To beat the papal monarch from our lands. (18.12-16)

In the notes to the Revels edition of the play, Oliver observes that Elizabeth "and Navarre, of course, did share a concern to defeat Catholicism in Europe," a concern in which Marlowe, as an English agent, served. ${ }^{33}$ On the surface, this, too, seems overtly propagandist, but if we remember that Navarre has already been tied to both Lorraine and the Guise through their mutual use of the phrase "country's good," this passage gains a darker valence. If Navarre is as untrustworthy as the Cardinal and the Guise, then how should the audience perceive his connection to Elizabeth? On the one hand, the alliance between Navarre (Henry IV) and Elizabeth was a political fact of $1592 / 3$. On another, as Penny Roberts astutely observes,

Henry of Navarre was to embrace Catholicism the year after Marlowe is thought to have written the play, lending his remarks about upholding the true faith as hollow a ring as Henry III's declarations of affection for the Guises. It may be argued that Marlowe, anticipating the conversion which was widely rumoured, was demonstrating yet again the cynical use of religion as a cloak for personal political gain - a cynicism which runs as a theme throughout the play. ${ }^{34}$

If, as Roberts suggests, Marlowe was aware of these rumors, then his mitigation of Navarre's heroism makes sense; however, there is still the matter of his relationship to Elizabeth, made more complicated by Henry III's (formerly Anjoy, and historically a former suitor of the Queen) sudden reversal of loyalty from the Guise to Navarre (and, by extension, Elizabeth).

When Henry discovers the Guise's intent to supplant him, he turns against his erstwhile ally, recognizing that the Guise's loyalty to Spain and the Pope opposes his role as a subject of France. This dichotomization of loyalty to religion versus loyalty to the state was commonplace in Elizabeth's England as an argument against permitting the practice of Catholicism, and Epernoun's claim that the Guise has acted "for the Pope's sake" (14.23) makes him a "traitor to the crown of France" (14.21), just as Recusancy marked English Catholics as (potential) traitors.

Henry's response to the Guise's protestations of loyalty once again summons the ghost of Mary Queen of Scots and the Bond of Association to the play: like Elizabeth's government, Henry convinces the Guise to pledge his loyalty upon pain of death, thereby justifying — as did the Privy Council with Mary — his execution for treason. Although Henry proclaims 
that "Guise, the King and thou are friends" (14.66), only a few lines later he tells Epernoun and the audience that "as I live, so sure the Guise shall die!" (14.94). Two scenes later, Henry literally invites the Guise to his death, reassuring him that "I am resolute $-/$. . / Not to suspect disloyalty in thee" (16.44-46) moments before he is murdered at Henry's command.

Standing over the Guise's corpse, Henry proclaims the end of religious broils in France, making explicit reference to a Protestant alliance between France and England:

KING HENRY This is the traitor that hath spent my gold

In making foreign wars and civil broils.

Did he not draw a sort of English priests

From Douai to the seminary at Rheims

To hatch forth treason 'gainst their natural Queen?

Did he not cause the King of Spain's huge fleet

To threaten England and to menace me?

Did he not injure Monsieur that's deceas'd? ${ }^{35}$

Hath he not made me the Pope's defence

To spend the treasure that should strengthen my land,

In civil broils between Navarre and me? (21.99-109)

It is worth remarking that the description of the Guise offering patronage to English Catholic sympathizers to migrate from England to Rheims was, Oliver observes, "historically correct - if hardly appropriate to Henry III, whose hatred of Guise had nothing to do with England." 36 Furthermore, as Clayton MacKenzie explains, "Henry's effusive praise for England and its queen is repeatedly undermined by his poverty of judgment, his ludicrous self-mythologization, and by the general moral treachery that pervades the play." 37

The injection of an Anglo-Gallic alliance thus serves as yet another indication of Marlowe's distrust of the Elizabethan government's religious policy. Like Henry, Marlowe's text seems to suggest, Elizabeth was more than willing to play politics with religious belief, making use of anti-Papal discourse when - and only when - it suited her interests. Similarly, neither regime shied away from ostensibly religiously-motivated violence when it helped to maintain their power; as Mathew Martin suggests,

It is precisely the amnesia of realpolitik that the play invites its audience to interrogate. The play does not give its Elizabethan audience the moral luxury of complete identification with the massacre's victims but, rather, presses the audience to recognize its own complicity in the historical trauma it dramatizes. ${ }^{38}$

Interestingly, Marlowe implicates himself in this accusation of complicity, quite literally, through the figure of the silent English Agent who appears 
in the play's final scene. Some critics even suggest that the Agent is meant to be Marlowe, although I would argue that the Agent is symbolic of the Elizabethan government's reach rather than a specific figure for the playwright himself. ${ }^{39}$ Yet as an agent of the English government, Marlowe participated in the perpetuation of religious violence in the service not of God or of the common good, but of politics. Massacre at Paris demonstrates that in the political game, no one is safe, and no one's hands are clean.

Once Henry begins to kill the Guisians, the clergy turn murderous, as well, as a Friar declares his intent to murder the King in order to revenge the deaths of Guise and Lorraine: "I am a friar of the order of the Jacobins, that for my conscience' sake will kill the King" (23.23-25). The Friar stabs Henry_- "He stabs the King with a knife as he readeth the letter, and then the King getteth the knife and kills him" (24.33.1-33.3) - but the King survives long enough to send a warning to England: "I'll send my sister England news of this, / And give her warning of her treacherous foes" (24.50-51). As he is dying, Henry sends for an English Agent, who acts as a witness of Henry's death to England. As such, it is possible to imagine that Henry's dying speech is being recited to the Queen by the Agent, rather than the king himself - a scenario made all the more plausible by the fact that Marlowe was not the only English Agent to participate in the public theaters: ${ }^{40}$

KING HENRY Tell her, for all this, that I hope to live,

Which if I do, the papal monarch goes

To wrack, and antichristian kingdom falls.

These bloody hands shall tear his triple crown

And fire accursed Rome about his ears.

I'll fire his crazed buildings, and incense

The papal towers to kiss the holy earth.

Navarre, give me thy hand: I here do swear

To ruinate that wicked Church of Rome

That hatcheth up such bloody practices,

And here protest eternal love to thee,

And to the Queen of England specially,

Whom God hath bless'd for hating papistry. (24.57-69)

Henry's dying proclamation - prophesying the (historical) continuation of France's religious wars - acts as much as a warning to the Elizabethan government as it is an historical observation of France; this point is made especially evident through the presence of the English Agent throughout this final scene, as he - and, through him, Elizabeth — presides over the death of Henry III and the transition of power to Henry IV (Navarre). That Henry's last words are to Elizabeth - "Salute the Queen of England in my name, / And tell her, Henry dies her faithful friend" (24.104-105) - further 
suggests the parallelism between French and English religious policies, and, furthermore, questions the intentions of both. Like many of Marlowe's plays, Massacre at Paris ends with a false resolution that promises not peace and security, but a future fraught with violence. As his audience was well aware, the religious wars in France would continue to rage (and would not end until after Marlowe's death) and the alliance between England and France would be tentative at best.

So, in light of the political nihilism of Massacre at Paris, how do we return to the idea of Marlowe as a cultural leader? Put simply, Marlowe was an advocate for peace and tolerance in an age where both were considered tantamount to treason. Interested in the unconventional-as a scholar, an author, a secret agent and a believer-Marlowe was a seeker of knowledge whose role as playwright and spy led him to see the things which divided his world and those things which united it. Through plays like Massacre at Paris, Marlowe sought to show his audience the price of their supposed safety: bloodshed, death and the division of friends and family against one another. In the process, he was willing to accept his own culpability - as the English Agent - in the machine of Elizabethan government, a responsibility that, some argue, led to his death on 30 May 1593 in the back room of a tavern at the hands of other agents. Whether we choose to believe that Marlowe was murdered in a brawl over a tavern bill or assassinated for finally having crossed one too many of the Privy Council's lines, Marlowe's legacy was one of testing boundaries - of propriety, of censorship, of belief and of loyalty. And in the process, he helped to reshape the world in which he lived.

\section{NOTES}

1. Mark Abbott, The Massacre at Paris: With the Death of the Duke of Guise, An Overview of Marlowe's Works (The Marlowe Society, 2011), 34.

2. Charles Nicholl, The Reckoning: The Murder of Christopher Marlowe (New York: Harcourt Brace \& Company, 1992), 100.

3. Marlowe attended Cambridge on a scholarship, as he would otherwise have been unable to afford to attend. The buttery kept careful records of student spending, particularly for scholarship students, in order to keep them within their allotted budget. Starting in 1585, Marlowe appears to have been in possession of additional cash that enabled him to spend money more freely.

4. Park Honan, Christopher Marlowe: Poet \& Spy (Oxford: Oxford University Press, 2005); David Riggs, The World of Christopher Marlowe, A John Macrae Book (New York: Henry Holt and Company, 2004); A.L. Rowse, Christopher Marlowe: His Life and Work (New York: Harper \& Row, 1964).

5. Riggs, 32.

6. Riggs, 32 .

7. Riggs, 33. 
8. Andrew Gurr, Shakespeare's Opposites: The Admiral's Company 1594-1625 (Cambridge: Cambridge University Press, 2009), 95.

9. Kristin M.S. Bezio, Staging Power in Tudor and Stuart English History Plays: History, Political Thought, and the Redefinition of Sovereignty (Aldershot: Ashgate Publishing, 2015).

10. Roy Kendall, Christopher Marlowe and Richard Baines: Journeys through the Elizabethan Underground (Madison, NJ: Fairleigh Dickinson University Press, 2003), 154.

11. Samuel A. Tannenbaum, The Assassination of Christopher Marlowe, Reprint (1928) (Hamden, CT: The Shoe String Press, 1962), 27.

12. Tannenbaum, 28.

13. Quoted in Kendall, 332.

14. George T. Buckley, Atheism in the English Renaissance (New York: Russell \& Russell, 1965), 50.

15. Leonard Smith, "Truth in a Heresy? 5. Socinianism," The Expository Times 112, no. 7 (1 April, 2001), 223.

16. Edgar C. Knowlton, "Marlowe and Poland," The Polish Review 28, no. 1 (1 January, 1983), 14; edition of Doctor Faustus used: Christopher Marlowe, Doctor Faustus: Aand B-Texts (1604, 1616), eds David Bevington and Eric Rasmussen, The Revels Plays (Manchester: Manchester University Press, 1995).

17. During the reign of Emperor Sigismund (1368-1437), the papacy was held by Urban V, Gregory XI, Urban VI, Boniface IX, Innocent VII, Gregory XII, Martin V and Eugene IV. Julius I was pope from 337-352, Julius II from 1503-1513, Julius III from 1550-1555 (overlapping with Sigismund of Poland for the entirety of his papacy).

18. Quoted in Kendall, 332.

19. Philip Henslowe, Henslowe's Diary, ed. Walter W. Greg (London: A.H. Bullen, 1904), 15; Kristen Elizabeth Poole, "Garbled Martyrdom in Christopher Marlowe's The Massacre at Paris," Comparative Drama 32, no. 1 (Spring 1998), 4. David Potter notes that the play would be bought by Edward Alleyn and taken to the Lord Admiral's Men and replayed from 1594 until 1601 ("Marlowe's Massacre at Paris and the Reputation of Henri III of France," in Christopher Marlowe and English Renaissance Culture, eds Darryll Grantley and Peter Roberts (Aldershot: Scholar Press, 1996), 71).

20. Potter, 70 .

21. Julia Briggs, "Marlowe's Massacre at Paris: A Reconsideration," The Review of English Studies, New Series, 34, no. 135 (1 August 1983), 259.

22. Briggs, 258.

23. John Guillory, "Marlowe, Ramus, and the Reformation of Philosophy," ELH 81, no. 3 (2014), 708.

24. Paul J. Voss, Elizabethan News Pamphlets: Shakespeare, Spenser, Marlowe, and the Birth of Journalism (Pittsburgh, PA: Duquesne University Press, 2001), 42.

25. Abbott, 52-3.

26. It is also well worth noting that Mary Stuart (Queen of Scots) was related by marriage to the Guises, a familial tie that further cements the link in the play between Mary and the Guise.

27. Presumably, the murder would have been staged on the gallery above the stage, then a dummy corpse thrown down to the main performing area below.

28. H.J. Oliver includes a note which reads: "Varamund says the head was sent to the Pope, and adds, 'Other cut off his hands, and other his secrete partes' (x, f.14v). One wonders whether it was Marlowe or the reporter who omitted the last gruesome detail" (note contained in Christopher Marlowe, Dido Queen of Carthage and The Massacre at Paris, ed. H.J. Oliver, The Revels Plays (London: Methuen \& Co., 1968), 112).

29. Ramus's death is itself extended and quite interesting. For further details, see John Ronald Glenn, "The Martyrdom of Ramus in Marlowe's The Massacre at Paris," Papers on Language and Literature 9 (1973), 365-79.

30. Paul H. Kocher, "François Hotman and Marlowe's The Massacre at Paris," Publications of the Modern Language Associations of America 56, no. 2 (1 June, 1941), 365. 
31. Elizabeth I, Elizabeth I Collected Works, eds Leah S. Marcus, Janel Mueller and Mary Beth Rose (Chicago, IL: The University of Chicago Press, 2000), 183-5.

32. Elizabeth I, 182.

33. Oliver, 139 (note).

34. Penny Roberts, "Marlowe's The Massacre at Paris: A Historical Perspective," Renaissance Studies 9, no. 4 (December 1995), 439.

35. The "Monsieur" mentioned in line 106 is the Duke of Alençon (d. 1584), brother to Henry III and Elizabeth's sometime suitor to whom she affectionately referred as her "Frog."

36. Oliver, 151 (note).

37. Clayton G. MacKenzie, Deathly Experiments: A Study of Icons and Emblems of Mortality in Christopher Marlowe's Plays, AMS Studies in the Renaissance 49 (New York: AMS Press, 2010), 77.

38. Mathew R. Martin, "The Traumatic Realism of Christopher Marlowe's The Massacre at Paris," English Studies in Canada 37, no. 3/4 (September 2011), 38.

39. Andrew M. Kirk, "Marlowe and the Disordered Face of French History," Studies in English Literature, 1500-1900 35, no. 2 (1 April 1995), 193.

40. Anthony Munday, another playwright and actor, and the author of a pamphlet which included an account of the St. Bartholomew's Day Massacre, The Mirrour of Mutabilitie (1579), also served as an agent for the Elizabethan government (Anthony Munday, The Mirrour of Mutabilitie, or Principall Part of the Mirrour for Magistrates Describing the Fall of Diuers Famous Princes, and Other Memorable Personages, Early English Books Online (London: Iohn Allde, 1579), $\$ 2 \mathrm{r}-\mathbb{C} 3 \mathrm{v}$ ); Stephen Alford, The Watchers: A Secret History of the Reign of Elizabeth I (New York: Bloomsbury, 2012), 67. 